\title{
STRUCTURE AND MANAGEMENT OF THE NATIONAL AUTOMATED SYSTEM FOR PERMANENT CONTROL OF THE RADIATION GAMMA BACKGROUND IN BULGARIA
}

\author{
Nicolai Todorov DOLCHINKOV \\ "Vasil Levski" National Military University, Veliko Tarnovo, Bulgaria \\ n_dolchinkov@abv.bg \\ Nicolai Bonev NICHEV \\ “Vasil Levski” National Military University, Veliko Tarnovo, Bulgaria \\ nicheff@abv.bg
}

\begin{abstract}
In the up-to-date complicated political situation it's imperative to monitor the status of the radiation background not only in Bulgaria, but also in Europe and worldwide. Since 1992 in Bulgaria operates an automated system for permanent control of the radiation gamma background (NASPCRGB). The system has been modernized by means of a European program during its last operation period and is connected with EURDEP - the European System for Exchange of Radiological Data of the European Commission. The operation of the System and its management are assigned to the Executive Environment Agency of the Ministry of Environment and Water Resources. In the present article we have shown the structure of the National Automated System for permanent control of the radiation gamma background (NASPCRGB) and its functions.
\end{abstract}

KEYWORDS: radiation background, control, management, probe, data

\section{Introduction}

After the radioactivity was discovered in the beginning of the century the scientists had considered, that only the soil and the rocks were a source of radiation into the atmosphere. Yet very soon it had been discovered that when the altitude increased (in experiments with balloons), also the radioactive radiations increased, resulting from the space radiation (Dolchinkov and
Nichev, 2016). Later it was found out, that the space radiation comprises two components: primary radiation - of galactic origin, penetrating into the atmosphere, and secondary space radiation - originating from the reaction of the cosmic rays with the nuclei of the air elements, with the space dust, precipitating on the planet and others. This activity results mainly from light radionuclides, such as: berrylium, 
sodium, aluminium, vanadium and others. The space rays, which are reaching the surface of the Earth, are able to create radio isotopes, but their radioactivity, compared to the other radionuclides of natural origin, is exceptionally low and is not of special significance (Pivovarova and Mikhalev, 2004).

The establishing of a National Automated System for permanent control of the radiation gamma background in Bulgaria (BULRaMo) dates back to1992 and was made by the German company "Hormann" - GmbH. It was put into operation in 1997. The authority, responsible for the establishing and maintenance of the System, is the Ministry of Environment and Water Resources. The Ministry for Environment and Water Resources submits the data, collected by the System, to the EURDEP - European Platform for Exchange of Radiation Data. This makes it possible to study the results of the radiation monitoring from most European countries, among them also from Bulgaria (Executive Environment

\section{System Structure}

The structure of the System is hierarchical and it's controlled by a computer and consists of:

A central monitoring Station to the Executive Environment Agency of the Ministry of Environment and Water Resources, called "central station" (CS);

A mobile monitoring station to the National Centre for Environment and Sustainable Development of the Ministry for Environment and Water Resources, called "mobile station" (MS);

Nine regional monitoring stations of the Regional Inspectorates for Environment and Water Resources in the cities: Burgas, Montana, Pleven, Plovdiv, Rousse, Sofia, St. Zagora, Vratsa and Varna, called "regional stations" (RS) (The Council of Ministers, 2013);

A reaction centre at the National Situation Centre of the Ministry of the Interior, situated at the Chief Directorate "National Protection of Population Service", called "reaction centre" (RC); Agency, 2017).

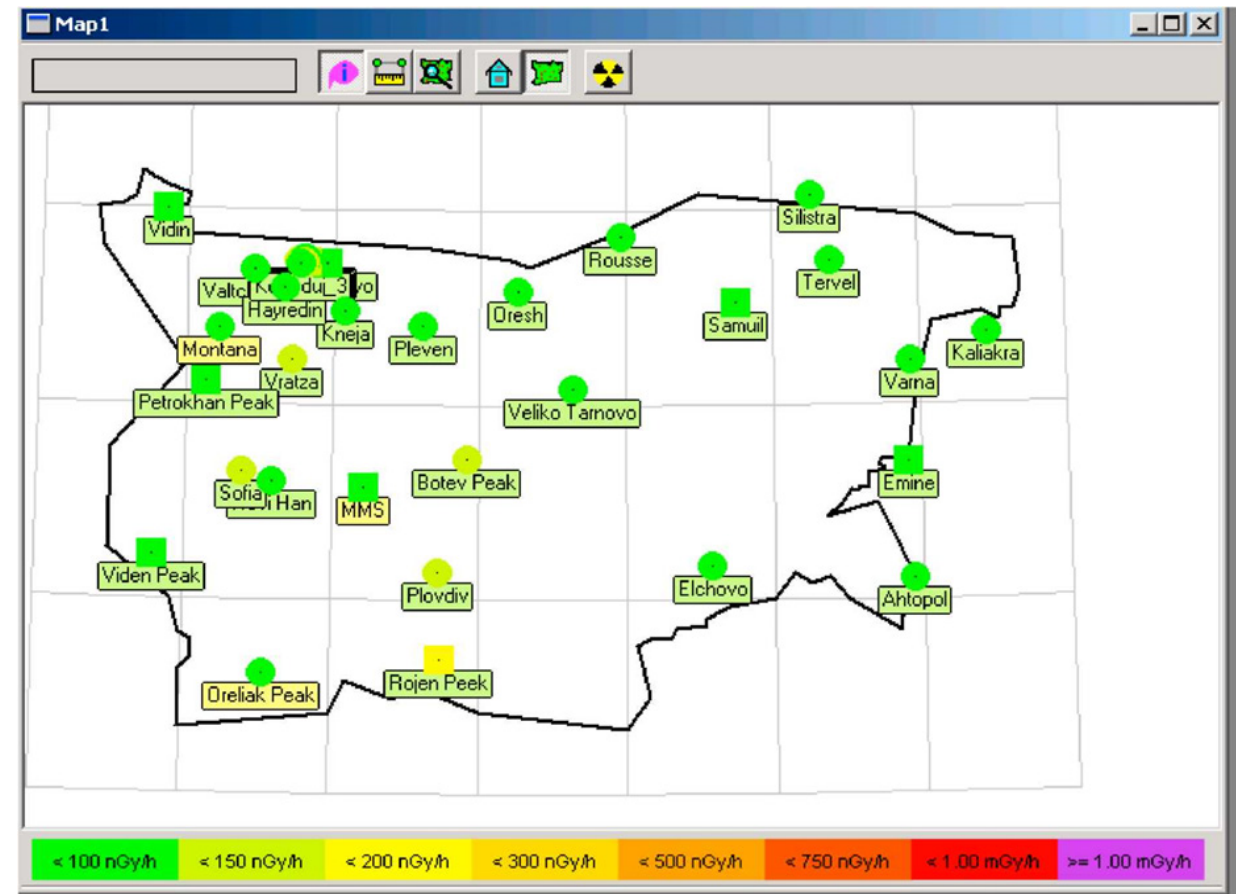

Figure no. 1: Location of the LMS on the map of Bulgaria (Executive Environment Agency, 2017) 
An emergency station of the Agency for nuclear regulation, situated at the Emergency Centre of the Agency, called "emergency station" (ES);

$>$ Twenty six local monitoring stations, called "local stations" (LS). National Automated System for permanent control of the radiation gamma background commands 26 Local monitoring stations, located in the towns of Vidin and Valchedram, in the village of Hayredin, in the town of Montana, in Selanovtsi village, in the towns Kneja, Vratsa, Veliko Tarnovo, at Petrokhan Peak, in the towns Pleven, Silistra, Rousse, Tervel, in Samuil village, at cape Kaliakra, at cape Emine, in Oresh village, in the towns Ahtopol, Varna, Elchovo, at Rojen Peak, in the town of Plovdiv, at Viden Peak, Oreliak Peak, Botev Peak and in Sofia (Figure no. 1) (Executive Environment Agency, 2017).

The general management, direction, coordination, control of the operating conditions of the local stations and of the mobile station, the processing and visualization of the information from the automated system in normal situation are performed by the Central station, and in emergency conditions - by the reaction centre (Dolchinkov, 2016).

The order of establishment, maintenance, exploitation and development of the automated system is specified in RCM No 434/19.11.1997, published in State Gazette Nr. 112/28.11.1999.

\section{System \\ 2.1. Composition and Scheme of the}

In 1997 the National Automated System for permanent control of the radiation gamma background began operating (BULRAMO).

In 1999 all Local monitoring stations (LMS) on the territory of Bulgaria had been completely put into operation and had been added to the System.

All measuring sensors have been refurbished, and in addition spectrometric gamma probes have been installed in 16 out of all 26 LMS. The company-manufacturer of the gamma-probes and of the rain detectors is ENVINET GmbH. The new installed components are:

1. A gamma probe: IGS421B-H, measuring capacity of the ambient equivalent dose in $\mu \mathrm{iSv} /$ ri (Figure no. 2) (Bulgarian Nuclear Regulatory Agency, 2016);

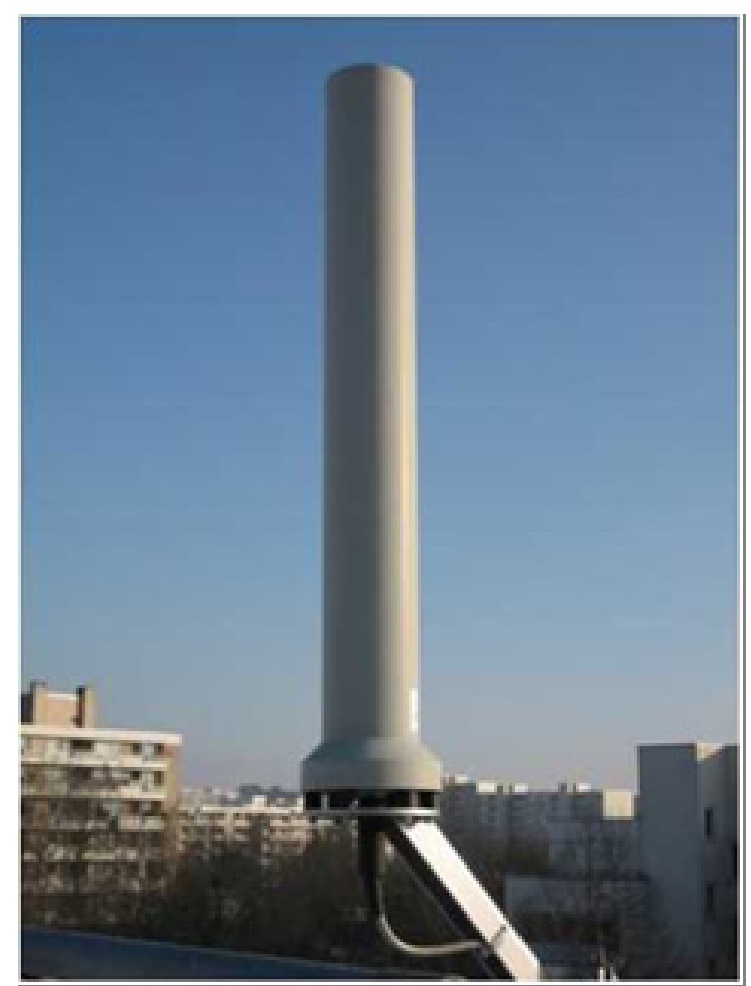

Figure no. 2: Appearance of the gamma probe IGS421B-H

(Bulgarian Nuclear Regulatory Agency, 2016)

2. Rain detector: RD203;

3. The data logger - DLM1440 has a selected ARM based processor module with an embedded Linux and Lan interface;

4. Spectrometric gamma probe SARA IGS 710/910 (NaI/LaBr3);

5. Communication equipment GPRS/3G and the communication equipment for the radio channels is preserved;

6. Meteorological stations - EEA has no obligation to measure the meteorological parameters, also due to the fact, that the main manufacturers of equipments for 
radiological monitoring systems in environment don't offer such equipment, the available meteorological stations are

preserved, but their refurbishing is not stipulated (Figure no. 3.) (Ministry of Environment and Water of Bulgaria, 2016).

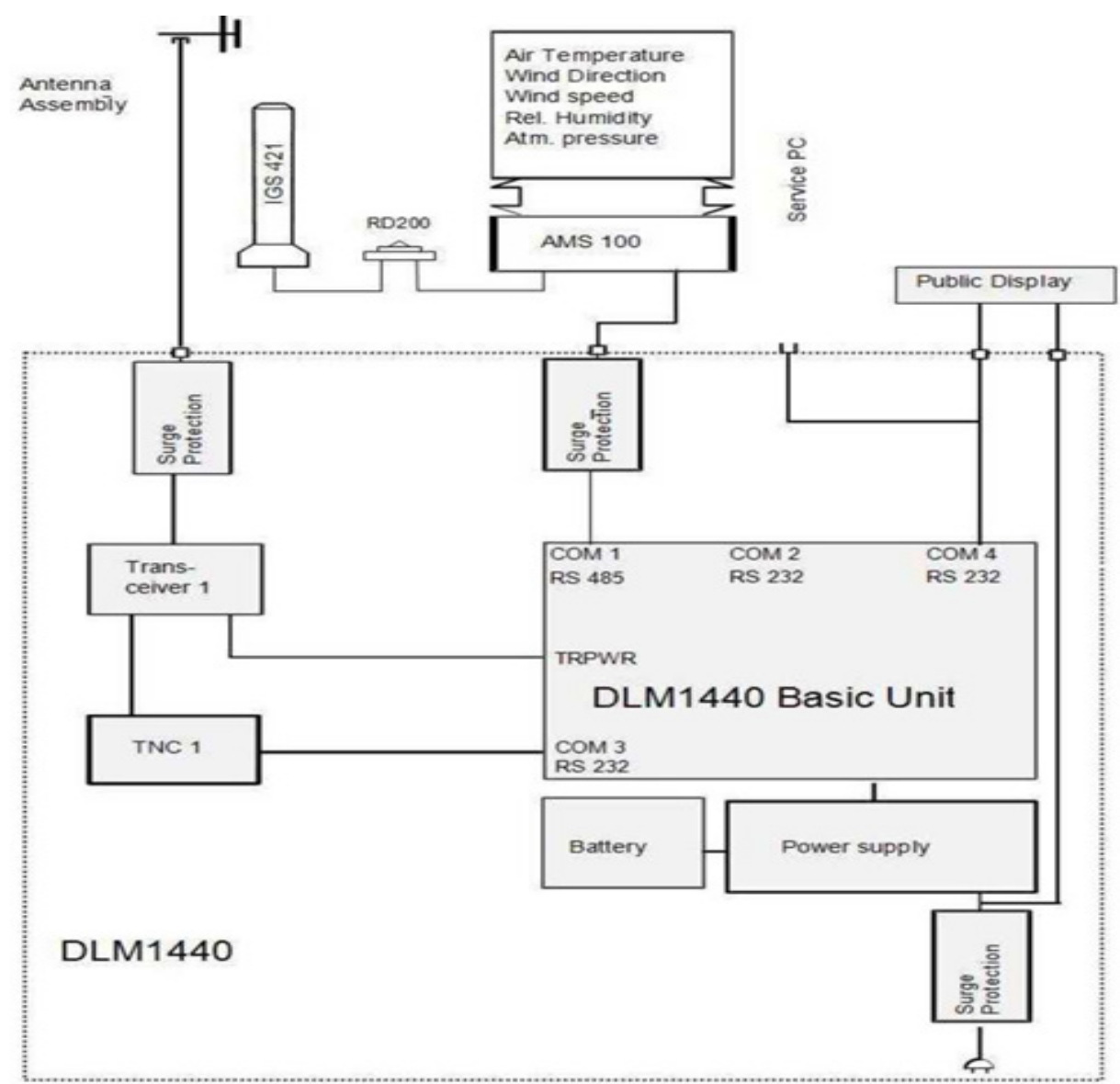

IGS 421 - интелигентна гама сонда

RD 200 - детектор за дъжд

DLM 1440 - компютьр дневник на данните / Data Logger

AMS - автоматична метрологична станция (опционно)

Figure no. 3: Block diagram of the LMS (Ministry of environment and water of Bulgaria, 2016)

\section{Management of NASPCRGB}

The management of the National Automated System for permanent control of the radiation gamma background BULRAMO is performed by experts of the Executive Environment Agency (EEA). EEA is subordinated to the Ministry of Environment and Water Resources and is directly responsible for the monitoring of a great number of environmental parameters, among them also the radiation situation (Council of Ministers, 2011).
The Executive Environment Agency comprises general and specialized administration. The general administration supports technically the activity of the Executive Director and of the specialized administration. It is organized into two Directorates:

Directorate "Finance, legal services, administration and human resources";

Directorate "Information service and technologies, international cooperation and public relations"; 
The specialized administration implements information, regulative, coordination and control functions according to the authorities of the executive director. It's differentiated into three directorates:

Chief directorate "Laboratory and analytical activity";

Directorate "Monitoring and evaluation of the environment";

Directorate "Permission regimes";

The directorate "Monitoring and evaluation of the environment" carries out the administrative management of the National Automated System for permanent control of the radiation gamma background and of the Automated system for radiation monitoring of the Danube river in the area around the Nuclear Power Plant "Kozloduy" (Vasilev, 2015). It works out and publishes national representative information about the condition of the environment and of the natural resources by means of:

- Daily Report about the quality of the atmosphere air across the country

- Daily Report about the situation of the radiation gamma background in the country;

- Three-month report about the situation of the environment in Bulgaria;

- A national annual report about the condition of the environment in Bulgaria (Ministry of environment and water of Bulgaria, 2016).

The Directorate consists of 6 departments and the Department for "Monitoring of the air, noise level and radiological monitoring" controls directly all the processes, connected with the radiation situation in Bulgaria, the measuring and the analysis of these indicators. The management tasks, facing the Department, can be generalized, as follows:

Works out reports according to the Law for access to public information (LAPI);
Administrates the network for radiologic monitoring of the environment atmospheric air, surface waters, soils, waste waters and products;

Administrates the National Automated System for permanent control of the radiation gamma background;

$>$ Administrates the Automated system for radiation monitoring of the Danube river in the area around the Nuclear Power Plant "Kozloduy";

Administrates the additional monitoring Centre of the "RODOS" System (Real-time On-line Decision Support) for support by taking of decisions in real time in case of nuclear accidents, situated in the Agency for nuclear regulation;

Participates in the elaboration and implementation of the Information Subsystem "radiological monitoring", part of the National System for Environmental Monitoring;

Collects, processes and evaluates the information, received from the National Network for radiological monitoring;

$>$ Fulfills the obligations of the Republic of Bulgaria according to the Contract for establishing the European Atomic Energy Community (EURATOM) to report to the European Commission about the data from the radiological monitoring of the environment;

Annually reports the data to the pan-European database - REM (Radiological monitoring of the environment);

$>$ Daily sends the data from the National Automated System for permanent control of the radiation gamma background to the European System for Radiological Data Exchange (EURDEP);

Works out the section: "Radiation situation of the Environment" for the purposes of the National Annual Report about the condition of the environment and for the three-months reports; 
Elaborates a daily Report about the condition of the radiation gamma background in the country;

$>$ Prepares the specialized information, reports and evaluations of the radiological state of the environment;

Implements the contacts and coordination with other departments and administrations of the Executive Environment Agency and of the Ministry of Environment and Water Resources;

$>$ Implements the contacts with other state authorities, connected with the activity of the Department.

Some of the functions, as for example the reporting to the European System for Radiological Data Exchange - EURDEP, must be managed in coordination with the Agency for Nuclear Regulation.

The management of BULRaMo comprises:

- Observation of the technical status of all the components of the automated system;

- Observation and analysis of the radiation status of the database of the obtained from the local monitoring stations data;

- Operation with the specialized software for management of BULRaMo;

- Maintenance of the database servers of BULRaMo;

- Observation of the communication channels and replication of data to the consumers of operational information from BULRaMo. Support to these consumers during their work at the Additional monitoring centers with the data from the system.

- Publishing of reports and inquiries with the obtained from BULRaMo data. Daily and three-month reports are being issued, which can be seen in real time on the web-page of the Executive Environment Agency. The Agency elaborates also annual reports about the condition of the environment, which contain a specialized section about the radiation status. The report is adopted by the Council of Ministers of Bulgaria and is also published on the web-page of the Executive Environment Agency;

- In case of a nuclear accident, elaboration of expert opinions about the radiation condition of the environment aiming to support the corresponding state authorities in taking management decisions;

- Periodical update of the system;

- Organizing the maintenance of the BULRaMo equipment using the help of an external service company;

- Solving all the rest technical and administrative problems, which occurred during the exploitation of BULRaMo (Executive Environment Agency, 2017).

\section{Conclusions}

The National Automated System for permanent control of the radiation gamma background has been established and is operating effectively. The System reads in real time the change of the natural radiation background and submits information to all concerned parties, which are consumers of the system.

The lack of a duplicating optical independent connection with chief authorities is the weakness of the system in the exchange of information, which in case of interruption of the internet connection can lead to missing information and missing collaboration between the authorities, which are responsible for the actions in case of radiation accident.

A very well organized control and action in case of a possible accident in the Nuclear Power Plant „Kozloduy“ in all areas around the Power Plant. The quality of the conducted trainings is on a very high level.

The operating National Automated System for permanent control of the radiation gamma background to the $\mathrm{AEE}$ and the System for observation and forecasting of the air masses in case of nuclear accident at the National Institute for 
Meteorology and Hydrology are well operating in real time systems for observation of the radiation background. They are built and updated in accordance with the requirements of Euratom, International Atomic Energy Agency and the EC.
The management of the National Automated System for permanent control of the radiation gamma background is performed professionally, according to the requirements of the international organizations and under the terms of our national and the international legislation.

\section{REFERENCES}

Bulgarian Nuclear Regulatory Agency. (2016). Annual report of 2015, Sofia: Bulgarian nuclear regulatory agency, available at: http://www.bnra.bg/en/documents-en/annrep/anrepeng-2015.

The Council of Ministers. (2011). National programme on disaster the 2014 -2018, Sofia: the Council of Ministers.

The Council of Ministers. (2013). National report on the status and protection of the environment in Bulgaria in 2012 of the EEA, Sofia: The Council of Ministers.

The Council of Ministers. (2014), National report on the status and protection of the environment in Bulgaria in 2013 of the EEA, Sofia: The Council of Ministers.

Dolchinkov, N.T. \& Nichev, N.B. (2016). Characteristics of radiation, Revista Academiei Forţelor Terestre, No. 2 (82).

Dolchinkov, N.T. (2016). Historical overview and analysis of national automated system for continuous mon itoring of gamma radiation, VIII научно-практического семинара Економічна безпека держави і науково-технологічні аспекти їі забезпечення, Кіів.

Executive Environment Agency. (2017). National report on the status and protection of the environment 2013 in the Republic of Bulgaria, available at: http://translate.google.com/translate? $\mathrm{u}=\mathrm{http} \% 3 \mathrm{~A} \% 2 \mathrm{~F} \% 2 \mathrm{Feea}$.government.bg $\% 2 \mathrm{Fbg} \% 2 \mathrm{Fsoer}$ $\% 2 \mathrm{~F} 2014 \&$ langpair $=$ autolen $\& \mathrm{hl}=\mathrm{en}$.

Ministry of Environment and Water of Bulgaria. (2016). National report on the Status and protection of the environment 2014 in the Republic of Bulgaria, available at: http://www5.moew.government.bg/?page id=44647.

Pivovarova, Yu. \& Mikhalev, V. (2004). Radiation ecology, Moscow. Academy.

Vasilev, D. (2015). Radioecology, Sofia. Titus Consult. 